\title{
Total polyphenol, tannin and flavonoid contents of Combretum micranthum leaves harvested in three regions of Senegal: Diass, Sandiara and Essyl.
}

\author{
Daba TINE, Alioune Dior FALL, Serigne Ibra Mbacké DIENG, Abdou SARR and \\ Emmanuel BASSENE*
}
Department of Pharmacognosy and Botany, Faculty of Medicine, Pharmacy and Odontology, Cheikh Anta Diop University, Dakar, Senegal.
*Corresponding author; E-mail: aynenut@gmail.com

\begin{abstract}
Combretum micranthum G. Don is a highly consumed plant in Senegal. Leaves collected at three sites in Senegal (Sandiara, Essyl and Diass) were compared for total polyphenols, tannins and flavonoids. The harvest periods selected are the rainy season period and the after rainy season. The contents of total polyphenols and tannins were determined by the reagent of Folin and Denis. Flavonoids are evaluated by a method using $\mathrm{AlCl}_{3}$. The results show that flavonoid contents, expressed as vitexine equivalent per $100 \mathrm{~g}$ of dry matter, during the rainy season and post-rainy season are respectively: Sandiara $0.63 \pm 0.45$ and $0.43 \pm$ 0.006; Essyl $0.31 \pm 0.021$ and $0.31 \pm 0.06$; Diass $0.69 \pm 0.07$ and $0.63 \pm 0.005$. The total polyphenol content expressed as tannic acid equivalent per $100 \mathrm{~g}$ of solids: Sandiara $8.5 \pm 1.31$ and $10.44 \pm 2.19$; Essyl $10.53 \pm 4.6$ and $17.17 \pm 0.73$; Diass $13.57 \pm 1.7$ and $16.37 \pm 0.69$; those of the tannins respectively: Sandiara $3.4 \pm 1.23$ and $5.1 \pm 2.08$; Essyl $4.63 \pm 1.6$ and $9.52 \pm 0.02$; Diass $8.51 \pm 1.25$ and $9.1 \pm 0.47$. These results show that leaves harvested in the post-rain season are richer in total polyphenols and tannins than those harvested during the rainy season; as far as flavonoids are concerned the differences are less noticeable.
\end{abstract}

(C) 2019 International Formulae Group. All rights reserved

Keywords: Combretum micranthum, tannins, flavonoids, total polyphenols.

\section{INTRODUCTION}

Combretum micranthum G. Don commonly known as kinkeliba is one of the most used plants in Senegalese traditional medicine. The pharmacological properties of the leaves justify that one was interested very early in their chemical composition. What makes many works have been done at this level among other study of the carbohydrate fraction highlighting of significant amounts of sorbitol, mannitol and m-inositol (Bassene, 1981); the presence of these compounds justifies the action of the plant on digestive disorders and safety action; the unsaponifiable fraction of the lipid extract of the leaves of C. micranthum shows the presence of fatty acids
(Bassene, 1986a), several aliphatic alcohols, two triterpenes alcohols and sterols (Bassene, 1989). We can also note the presence of alkaloids like hydroxystachydrine, stachydrine and choline (Bassene, 1986b), what justifies the cholagogue activity and partly the lipotropic activity. Vitexin and the isovitexine are considered the major flavonoids in leaves (Bassene, 1987). Polyphenols having glucoselowering activities were found in the leaves extracts (Welch, 2018). However the study of variability of polyphenol content addressed in this present work has never been a subject of investigation. There are $C$. micranthum in parts of Senegal with different rainfall. Three 
sites interested us: Diass in the Thies Plateau, Sandiara in the Peanuts Basin and Essyl in Casamance south of Senegal. The total rainfalls are respectively with a: $351.7 \mathrm{~mm}$; $497.2 \mathrm{~mm}$ and $1451.8 \mathrm{~mm}$.

\section{MATERIALS AND METHODS Plant material}

Series of leaf harvests were performed in 2016 and 2017 in period of the rainy season and after the rainy season in various sites: Sandiara: the rainy season (July, August, September); after the rainy season (December, January); Diass: the rainy season (July and September), post the rainy season (January); Essyl: the rainy season (August), post the rainy season (January). The leaves are then dried in the shade then powdered. The water content is evaluated by loss to desiccation.

\section{Polyphenols contents}

Phenolic contents of $C$. micranthum extracts was estimated by the Folin and Denis method (Dieng, 2015). $20 \mathrm{~g}$ of leaf powder are extracted by decoction with triple $250 \mathrm{ml}$ of ethanol for 15 minutes at $95{ }^{\circ} \mathrm{C}$. The resulting extract was completed in 1 litre then diluted 1 : 100. To $10 \mathrm{ml}$ of the previous diluted solution add $2 \mathrm{~mL}$ of the Folin and Denis reagent, three minutes later add $2 \mathrm{~mL}$ of a saturated solution of sodium carbonate $\left(\mathrm{Na}_{2} \mathrm{CO}_{3}\right)$. After 4 minutes centrifugation at 4000 RPM, the absorbance was read at $670 \mathrm{~nm}$.

\section{Tannins contents}

This assay was based on the principle that the tannins have the property to bind into the casein. The concentration of tannins (TT) is deducted from that of total polyphenols (PT) and residual polyphenols (PR) by the relationship: $\mathbf{T T}=\mathbf{T P}$ - RP

To $30 \mathrm{ml}$ of the diluted extract operating mode previously, we add $3 \mathrm{~g}$ of casein. After 3 hours of magnetic agitation, the solution is filtered and the filtrate adjusted to $30 \mathrm{~mL}$. A $10 \mathrm{ml}$ of the filtrate add $2 \mathrm{~mL}$ of Folin and Denis reagent then three minutes later, $2 \mathrm{~mL}$ of a saturated solution of sodium carbonate $\left(\mathrm{Na}_{2} \mathrm{CO}_{3}\right)$. After centrifugation at $4000 \mathrm{rpm}$ for 4 minutes, the absorbances are measured at $670 \mathrm{~nm}$. The contents in polyphenols and tannins are expressed in tannic acid equivalent per $100 \mathrm{~g}$ of dry matter
(TAE/100 g). They have been determined from a calibration line established with tannic acid, treated in the same way as samples at different concentrations $(0.5 \%, 1 \%, 1.5 \%$, $1.7 \%, 2 \%)$.

\section{Flavonoids contents}

The dosage of flavonoids is made according to the principle that they give yellow color with $\mathrm{AlCl}_{3}$. The intensity of this color is measured at $430 \mathrm{~nm}$.

\section{Extraction}

$5 \mathrm{~g}$ powder of $C$. micranthum leaves are submerged in $200 \mathrm{ml}$ of ethanol, containing $0.5 \mathrm{~g}$ of calcium carbonate $\left(\mathrm{CaCO}_{3}\right)$. It keeps boiling under reflux for 30 minutes at $95{ }^{\circ} \mathrm{C}$; after filtration, a second extraction with $200 \mathrm{ml}$ of methanol is performed on the residue. The two extracts are combined and evaporated dry; the residue is taken up by a mixture of methanol - water (3$1)$; filtered on cotton and adjusted to $20 \mathrm{ml}$.

\section{Dosage}

$1 \mathrm{ml}$ of this last solution was diluted to $25 \mathrm{ml}$ with methanol. To $2 \mathrm{ml}$ of this dilution, add successively $3 \mathrm{ml}$ aluminum chloride $2.5 \%$ in water, $5 \mathrm{ml}$ of an aqueous solution of sodium acetate $10 \%$; then adjust to $25 \mathrm{ml}$. The reading is made 40 minutes later at $430 \mathrm{~nm}$ with a white without $\mathrm{AlCl}_{3}$ (SOMBIE, 2018). The flavonoids contents were expressed in vitexin equivalent for $100 \mathrm{~g}$ of dry matter (VE/100 g). They have been determined from a calibration line established with vitexin, treated in the same way as samples to various concentrations $(1 \%, 3 \%, 5 \%, 7 \%, 9 \%)$.

\section{RESULTS}

The equation of the regression line of the tannic acid calibration curve obtained is: $\mathrm{y}$ $=47.433 \mathrm{x}-0.0158 ; \mathrm{R}^{2}=0.9911$ and that of the vitexin calibration curve obtained is: $\mathrm{y}=$ $11.566 \mathrm{x}-0.1805 ; \mathrm{R}^{2}=0.9175$. Table 1 gives the results obtained in the different sites and harvest periods.

It was noted that for the three sites, that the period after rainy season is more favorable for the maximum of polyphenols and tannins, and less favorable for flavonoids. The leaves harvested at Diass and Sandiara are richer in flavonoids than those harvested at Essyl. 
Table 1: Total polyphenols, tannins and flavonoids contents in the leaves of Combretum micranthum.

\begin{tabular}{lcccc}
\hline $\begin{array}{l}\text { Places and periods } \\
\text { of harvest }\end{array}$ & Total Polyphenols TAE/100 g & Tannins TAE/100 g & Flavonoids VE/100 g \\
\hline Diass & RS & $13.57 \pm 1.7$ & $8.51 \pm 1.25$ & $0.69 \pm 0.07$ \\
& ARS & $16.37 \pm 0.69$ & $9.1 \pm 0.47$ & $0.63 \pm 0.005$ \\
& RS & $8.5 \pm 1.31$ & $3.4 \pm 1.23$ & $0.63 \pm 0.45$ \\
Sandiara & ARS & $10.44 \pm 2.19$ & $5.1 \pm 2.08$ & $0.43 \pm 0.06$ \\
& RS & $10.53 \pm 4.6$ & $4.63 \pm 1.6$ & $0.31 \pm 0.021$ \\
Essyl & ARS & $17.17 \pm 0.73$ & $9.52 \pm 0.02$ & $0.31 \pm 0.06$ \\
\hline
\end{tabular}

RS: Rainy Season $\quad$ ARS: After Rainy Season TAE: Tannin Acid Eq, VE; Vitexin Eq

\section{DISCUSSION}

The quantitative study of the leaves of Combretum micranthum shows interesting content in total polyphenols, tannins and flavonoids which confirms Bassene (1985). Indeed, this author had found for leaves harvested in October and December at Nguekokh (close to Diass) the respective contents in flavonoids $0.8 \%$ and $1.2 \%$ levels expressed in vitexin equivalent.

This variation of phenolic compounds content could be due both to water stress and the nature of the soil of sites (Odhiambo, 2017). So the leaves collected on sites with ferruginous soils like Diass are richest in flavonoids and polyphenols than those of low ferruginous soil like Sandiara and Essyl.

\section{Conclusion}

This study shows a variation of the levels of polyphenols compound according to the sites and the harvest periods, variation that seems to be related to the nature and the soil moisture.

\section{COMPETING INTERESTS}

The authors declare that they have no competing interests.

\section{AUTHORS' CONTRIBUTIONS}

DT: Harvesting in the different sites, performing dosages; SIMD and AS: supervision of Daba Tine in the implementation of tests; ADF and EB: Supervision of the research team.

\section{REFERENCES}

Bassene E, Olschwang D, Pousset JL. 1981. Caractérisation de l'inositol et du sorbitol, principes actifs probables du kinkéliba Combretum micranthum G. DON. Dakar Médical, 26(2) : 219-225.

Bassene E, Miralles J, Olschwang D, Pousset JL. 1986a. Acide gras des feuilles de Combretum micranthum G. Don (Kinkéliba). Herba Hungarica, 25(2): 7 14.

Bassene E, Olschwang D, Pousset JL. 1986b. Les alcoloides du Combretum micrathum G. Don (kinkéliba). Annales 
Pharmaceutiques Francaise, 44(3): 191-196.

Bassene E, Olschwang D, Pousset JL. 1987. Flavonoïdes du Combretum micranthum G. DON (Kinkéliba). Plantes Médicinales et Phytothérapie, XXI (2) : 173-176.

Bassene E, Olschwang D, Pousset JL. 1989. Etude de l'insaponifiable de l'extrait lipidique des feuilles de Combretum micranthum G. Don. (Kinkéliba). Herba Hungarica, 28(1-2): 75-79.

Dieng M, Fall DF, Diatta K, Diatta W, Bassene E. 2017. Dosage des polyphénols et activité anti-oxydante de feuilles et d'inflorescences mâles de Borassus aethiopum Mart. (Arecaceae). Int. J. Biol. Chem. Sci., 9(1): 1067-1071.
Odhiambo PO, Mildred PN, Winfred M, Joseph PGO. 2017. Water Stress Effect on Total Antioxiant Activity and Total Phenolic Content of Solanum scabrum Mill and Solanum scabrum in Kiambu, Kenya. Int. J. Biochem.Res \& Rev., 17(1): 1-9.

Sombie EN, Tibiri A, N'Do JYP, Traore TK, Ouedraogo N, Hilou A, Guissou PI, Nacoulma OG. 2018. Ethnobotanical study and antioxidant activity of antihepatitis plants extracts of the COMOE province, Burkina Faso. Int. J. Biol. Chem. Sci., 12(3): 1308-1319. 